\title{
Author Correction: Synergistic effect of human Bone Morphogenic Protein-2 and Mesenchymal Stromal Cells on chronic wounds through hypoxia-inducible factor-1 $\alpha$ induction
}

\author{
Sabine François ${ }^{1,2}$, Véronique Eder ${ }^{1,3}$, Karim Belmokhtar $^{3}$, Marie-Christine Machet ${ }^{3}$, \\ Luc Douay ${ }^{2}$, Norbert-Claude Gorin ${ }^{2}$, Marc Benderitter ${ }^{1}$ \& Alain Chapel ${ }^{1,2}$ \\ Correction to: Scientific Reports https://doi.org/10.1038/s41598-017-04496-w, published online 27 June 2017
}

The original version of this Article contained a typographical error in the spelling of the authors Alain Chapel and Véronique Eder, which were incorrectly given as Chapel A. Alain and Véronique V. Eder. This has now been corrected in the PDF and HTML versions of the Article.

(i) Open Access This article is licensed under a Creative Commons Attribution 4.0 International c. License, which permits use, sharing, adaptation, distribution and reproduction in any medium or format, as long as you give appropriate credit to the original author(s) and the source, provide a link to the Creative Commons license, and indicate if changes were made. The images or other third party material in this article are included in the article's Creative Commons license, unless indicated otherwise in a credit line to the material. If material is not included in the article's Creative Commons license and your intended use is not permitted by statutory regulation or exceeds the permitted use, you will need to obtain permission directly from the copyright holder. To view a copy of this license, visit http://creativecommons.org/licenses/by/4.0/.

(C) The Author(s) 2018

\footnotetext{
${ }^{1}$ Laboratory of Research on Irradiated Healthy Tissue Regeneration (LR2I), Institute for Radiological Protection and Nuclear Safety (IRSN), F-92260, Fontenay-aux-Roses, France. ${ }^{2}$ Proliferation and Differentiation of Stem Cells, Centre de Recherche Saint-Antoine (CRSA), UMR_S938, Faculté de médecine Pierre et Marie Curie, France Institut National de la Santé et de la Recherche Médicale (INSERM) U938, 27 rue de Chaligny, 75012, Paris, Paris, France. ${ }^{3}$ LAB.P.ART.-EA3852 Faculty of Medicine, University of Tours, 2 bis boulevard Tonnellé, 37000, Tours, France. Sabine François and Véronique Eder contributed equally to this work. Correspondence and requests for materials should be addressed to A.C. (email: alain.chapel@irsn.fr)
} 